\title{
Finite strain variation across the Mahabharat Thrust in central Nepal Himalaya
}

\author{
*Deepak Chamlagain and Daigoro Hayashi \\ Simulation Tectonics Laboratory, Faculty of Science \\ University of the Ryukyus, Nishihara, Okinawa 903-0213, Japan \\ (*Email:dchamlagain@hotmail.com)
}

\begin{abstract}
This paper deals with the three-dimensional strain across the Mahabharat Thrust (MT) in the Malekhu area in central Nepal. The MT served as a glide plane for the Kathmandu Nappe. Its footwall is made up of phyllites, quartzites, and amphibolites, whereas the hanging wall contains garnetiferous schists, biotite schists, and quartzites with a few lenses of augen gneiss. A three-dimensional strain analysis reveals that Nadai's amount of strain intensity $\left(\bar{\varepsilon}_{s}\right)$ ranges from 0.396 to 0.575 in the footwall indicating an increasing trend towards the proximity of the MT. In contrast, the hanging wall shows an increase in $\bar{\varepsilon}_{s}$ magnitude away from the MT and its value varies between 0.556 (at the basal part) and 0.795 (upper part). Microtextures and structures revealed dynamic recrystallisation of the footwall and static recrystallisation of the hanging wall rocks. The shape of three dimensional strain ellipsoids, types of microstructures, and mechanisms of grainscale deformation indicated that the footwall was dominantly affected by simple shear deformation at lower temperatures while the hanging wall suffered from pure shear with minor sub-simple shear deformation at relatively higher temperatures.
\end{abstract}

\section{INTRODUCTION}

The Himalayan range exhibits a prominent arcuate shape and includes several south-vergent intracrustal thrusts. The Main Central Thrust (MCT), Main Boundary Thrust (MBT), and Main Frontal Thrust (MFT) are the most important ones (Gansser 1964; Le Fort 1975; Valdiya 1980), respectively from north to south. The MCT separates the Higher Himalaya in the north from the Lesser Himalaya in the south. There is also the South Tibetan Detachment System (STDS) of normal faults towards the top of the Higher Himalayan sequence (Burchfield et al. 1992). On the other hand, the MBT separates the Lesser Himalayan succession from the Siwaliks lying to the south. The Siwaliks are further thrust over the sediments of the Gangetic plain along the MFT (Fig. 1). These rock successions are very distinct in their lithology and deformation pattern. Apart from these main tectonic features, there are also other thrusts, nappes, and klippen. The sole thrusts along which these nappes have been emplaced are sometime difficult to correlate with the intracrustal thrusts (Rai et al. 1998; Rai 2001; Upreti and Le Fort 1999; Johnson et al. 2001).

The Mahabharat Thrust (MT) lies in central Nepal along which the Kathmandu Nappe was emplaced ca 8 Ma ago (Arita et al. 1997, Arita et al. 2001; Takagi et al. 2003). Although the Himalayan thrust sheets are relatively well known (Brunnel 1986; Schelling and Arita 1991; Srivastava and Mitra 1994; DeCelles et al. 2001), quantitative data on their three dimensional strain variation during thrusting are generally less understood and more variable (Sanderson 1982). The analysis of three-dimensional strain is very important for calculating the total shortening in the deformed rock, as the internal deformation may constitute a significant component of bulk translation. Likewise, the analysis of micro- and mesoscale structures can shed light on the deformation mechanisms during thrusting. Consequently, this study focuses on the strain geometry, microstructures, and deformation mechanism across the MT.

\section{LITHOSTRATIGRAPHY}

In central Nepal, the rocks belonging to the Kathmandu Complex are thrust over the Nawakot Complex along the MT (Stöcklin and Bhattarai 1977). Present study area (Figs. 1 and 2) covers the upper part of the Nawakot Complex constituting the footwall and the lower part of the Kathmandu Complex comprising the hanging wall. In this area, the Nawakot Complex is made up of the Dhading Dolomite, Benighat Slates, Malekhu Limestone, and Robang Formation (phyllites, amphibolites, quartzites), respectively from bottom to top. The phyllites with intensely sheared quartzites of the Robang Formation form a mylonite zone in the footwall. The Nawakot Complex shows a gradual increase in the grade of metamorphism (from chlorite to garnet) towards the upper part, just below the MT (Johnson et al. 2001; Rai 2001).

The Kathmandu Complex lies above the MT and includes the lower formations of the Bhimphedi Group (Figs. 2 and 3 ) represented by garnetiferous schists, kyanite schist, and augen gneiss, which are extensively crosscut by several pegmatite veins. The basal part of the Bhimphedi Group (i.e. 
Raduwa Formation) forms a mylonitic shear zone and is overlain by the Bhainsedobhan Marble. The Kalitar Formation succeeds the marble, and is composed of dark green-grey two-mica schists with the intercalation of strongly micaceous quartzites. Overlying the Kalitar Formation, Chisapani Quartzite (Fig. 3) is characterised by white, thin to thick-bedded orthoquartzite showing strong cross-bedding and it is followed by the biotite schists and quartzites of the Kulikhani Formation.

\section{Structure of MT}

In the study area, the MT served as a glide plane along which the Kathmandu Complex was emplaced towards the south from its root zone. The entire thrust sheet has an oval shape and forms the Mahabharat Synclinorium (Stöcklin and Bhattarai 1977). In the Malekhu Khola, about 100 m thick mylonite and phyllonite zones characterise the MT. The NESW trending MT represents a thin ductile zone with the highest degree of finite deformation. It is distinctly marked by a penetrative foliation as well as stretching and mineral lineations. Deformation fabric intensities are generally homogeneous at the outcrop scale. The foliation in quartzites and schists is defined by aligned biotite and muscovite flakes. The mineral lineation in schists is defined by streaking of micas on foliation surfaces whereas in quartzites by a parallel alignment of quartz grains. In the footwall, platy phyllites display a lineation with south-southwest plunge and the foliation shows a steep dip towards the south (Fig. 3). Near the MT, mylonitic quartzite is characterised by a strong stretching lineation with southwest plunge. The S-C fabric at the MT zone shows a top-to-the-south shear sense.
In the central part of the MT shear zone, quartz veins are often folded asymmetrically and their axial planes are subparallel to the foliation plane. Garnet grains of centimetre scale are normally present in the MT zone. At the base of the hanging wall, the garnetiferous schist (Raduwa Formation) is well foliated with poorly developed linear structures. The foliation is dominantly dipping due south except near the MT, where it is either vertical or steeply dipping due north (Fig. 3).

\section{D strain analysis method}

From each oriented sample, three oriented thin sections were cut approximately perpendicular and parallel to the foliation plane. Then, photographs of thin sections were taken, their grain outlines were digitised, and best-fit grain ellipses were calculated. From the grain ellipses of each thin section, a final grain shape was computed applying the leastsquare method to estimate the two-dimensional strain, and the results of three respective thin sections were combined to obtain a final three dimensional strain ellipsoid (Hayashi 2001; see Appendix).

In the study area, the footwall comprises phyllites, quartzites, and schists, whereas the hanging wall consists of a thick succession of quartzite, gneiss, and schist. The quartzite contains inequant clasts having distinct measurable elliptical grain boundaries with a uniform to mildly undulatory extinction. In the schists, quartz grains are also elliptical with distinct grain boundaries. Hence, these quartz grains were taken as tectonic strain markers. Several studies (Jain and Anand 1988; Kawamitsu and Hayashi 1991; Mukul and

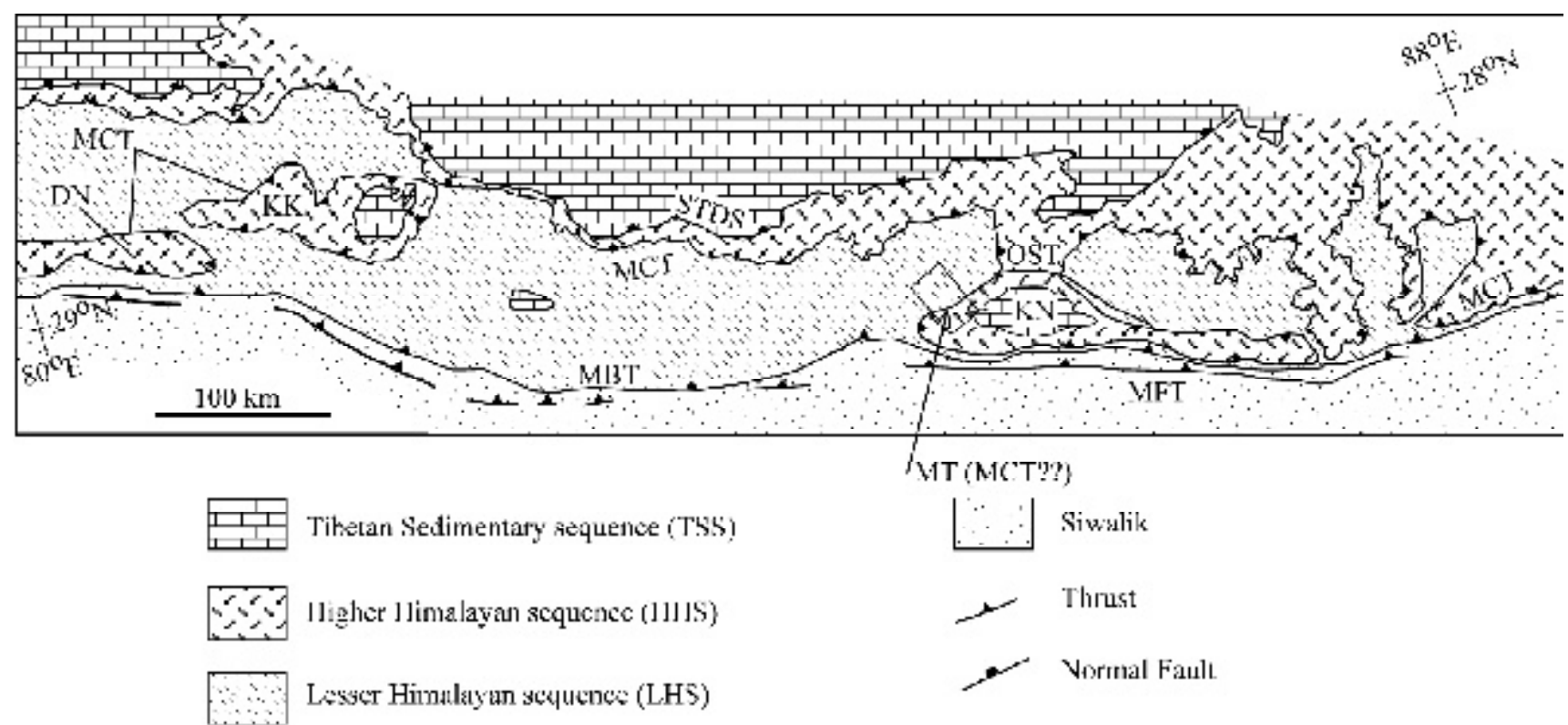

Fig. 1: Geological outline of Nepal Himalaya (modified after Kizaki and Hayashi, 1984, unpublished data); the rectangle depicts the study area. STDS: South Tibetan Detachment System, MCT: Main Central Thrust, MT: Mahabharat Thrust, OST: Out of Sequence Thrust, MBT: Main Boundary Thrust, MFT: Main Frontal Thrust, KN: Kathmandu Nappe, KK: Karnali Klippe, DN: Dadeldhura Nappe 


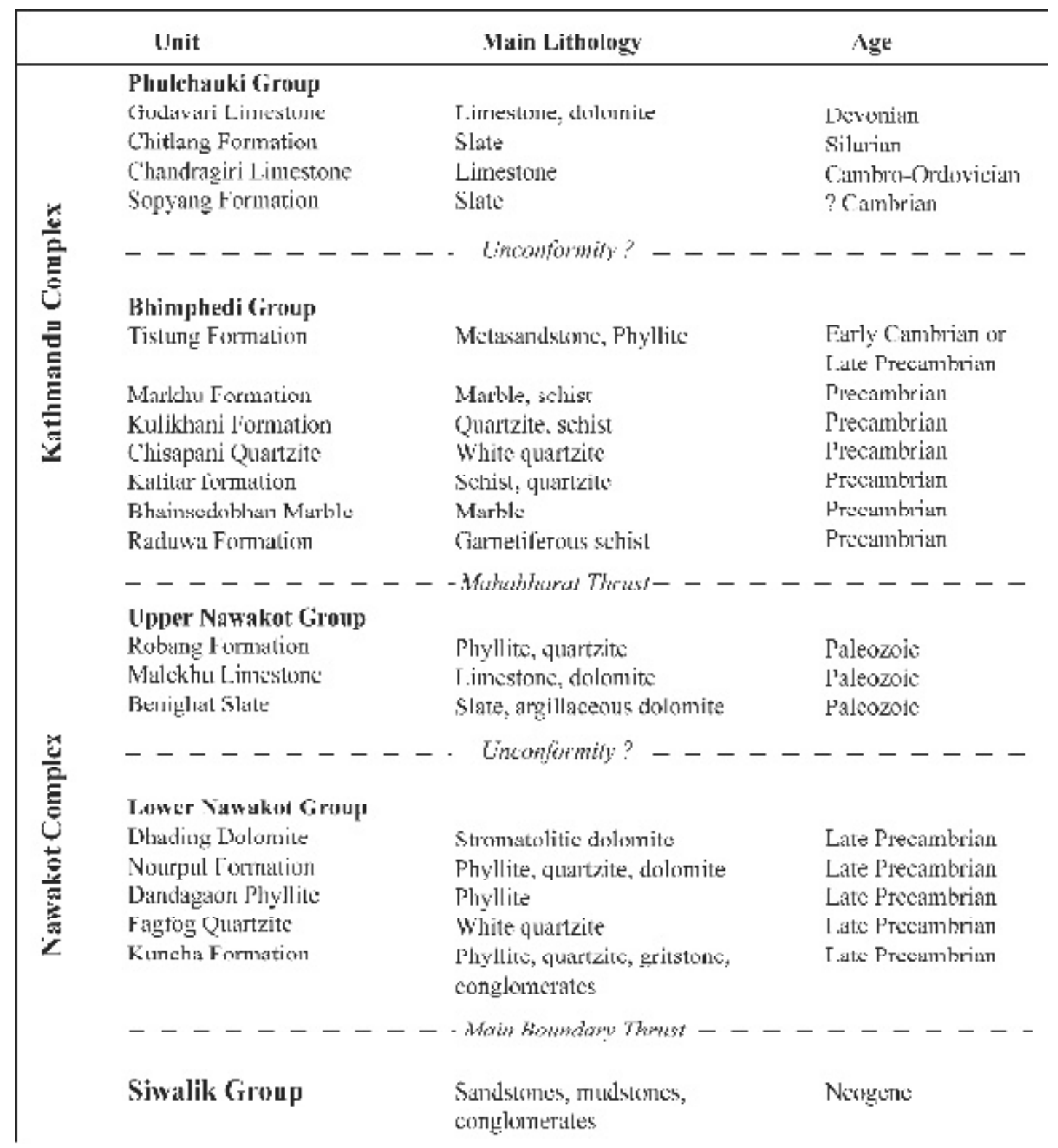

Fig. 2: Tectono-stratigraphic column of central Nepal (after Stöcklin 1980)

Mitra 1998) have also indicated that the quartz grains of a metamorphic terrain can be used as tectonic markers for computing the finite strain. Even the partly recrystallised ones (Strine and Wojtal 2004) were also useful for kinematic interpretations. For the precision of the analysis, however, we cautiously avoided the samples with recrystallised quartz grains exhibiting obscured boundaries. Further, we assumed that the quartz grains were initially randomly oriented, had elliptical shapes, and they showed a negligible ductility contrast with the matrix during a homogeneous deformation. Since the analysed quartzite specimens contained mainly quartz grains, they bore a minimum compositional heterogeneity and hence a minimum ductility contrast. In case of schists, only a selective portion of the thin section with a maximum proportion of quartz grains was considered for the analysis to minimise the effect of competence contrast. Up to 150 grains per thin section were considered for the analysis.

\section{RESULTS}

\section{Strain variation across the footwall of the MT}

In the Malekhu area, altogether twelve oriented samples were collected across the MT. The samples were evenly spaced. Five of them were taken from the MT footwall and seven from its hanging wall. Among them, four samples were of schist and the rests were of quartzite. The computed strain parameters vary according to the distance from the MT, lithology, and degree of deformation. The quartzite sample 


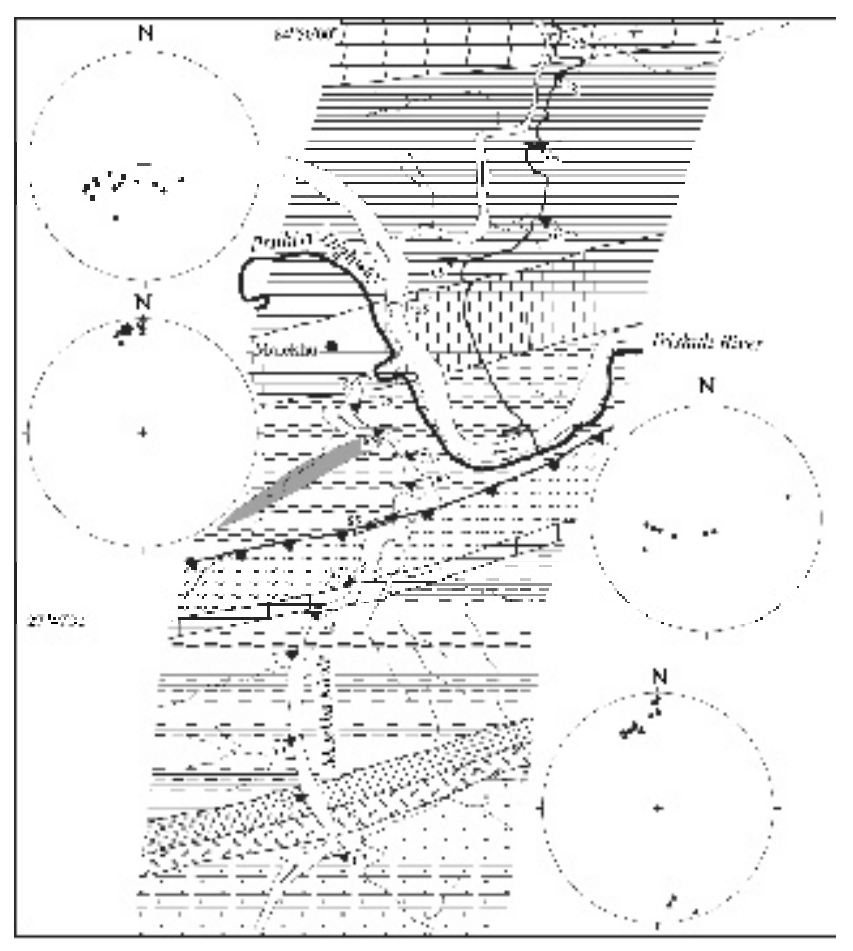

Lepend

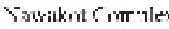

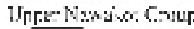

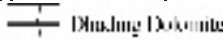

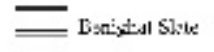

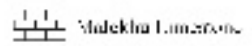

---- kokulg to wontrol

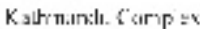

Rimphis

¿Z Rec:ina Tar waron

=干 Th:mosicth:c: Surbls

$\bar{z}=$ Kaliur Tur.asikm

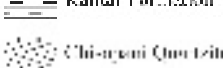

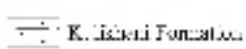

Fig. 3: Geological map of Malekhu area with structural data

(S.N. 9) taken from about $1 \mathrm{~km}$ below the MT gave a lower amount of strain intensity $\left(\bar{\varepsilon}_{s}\right)$ (Nadai 1963) of about 0.406 (Fig. 4). This sample is weakly foliated and represents the lowest part of the mylonite zone. The $\bar{\varepsilon}_{s}$ value decreases to 0.396 in a sample near the MT (S.N. 29), where rocks are weakly deformed and sheared. This trend, however, does not continue while moving further close to the MT. The degree of deformation and mylonitisation gradually increase and quartzites are intensely sheared. The $\bar{\varepsilon}_{s}$ value also gradually increases. The quartzite sample taken from about $300 \mathrm{~m}$ below the MT (S.N. 28) shows a relatively higher $\bar{\varepsilon}_{s}$ value of 0.497 than the samples from the lower structural levels of the footwall. This trend continues towards the thrust surface and the magnitude of $\bar{\varepsilon}_{s}$ increases to 0.575 for a quartzite sample (S.N. 27) taken from a few metres below the MT. The strain intensity, $\bar{\varepsilon}_{s}$, in the footwall generally increases towards the proximity of the MT (Fig. 4). The strain pattern, therefore, depicts a complex pattern of deformation probably due to the shearing effect.

\section{Strain variation across the hanging wall of the MT}

The hanging wall is composed of garnetiferous schist, biotite schist, quartzite, and augen gneiss. The magnitude of $\bar{\varepsilon}_{s}$ is higher for the hanging wall samples. Close to the MT, the $\bar{\varepsilon}_{s}$ value for a highly deformed schist (S.N. 26) is 0.556 (Fig. 4). This sample is representative of the MT zone schist, where many intrafolial folds and folded quartz veins are extensively developed. The $\bar{\varepsilon}_{s}$ value increases above the MT and reaches 0.684 (S.N. 24) for the lineated biotite schist. This general trend of increasing $\bar{\varepsilon}_{s}$ value is interrupted at the basal part of the Kalitar Formation, just above the marble unit and is decreased to 0.553 (S.N. 23). This may be due to a change in composition and competence contrast. Towards a higher structural level, the magnitude of $\bar{\varepsilon}_{s}$ increases significantly giving the highest value of 0.795 (S.N. 22) for the biotite schist of the Kalitar Formation. Intense layer-parallel shearing and $\mathrm{S}-\mathrm{C}$ fabrics in thin section characterise this area of high strain zone. Above this zone, the $\bar{\varepsilon}_{s}$ value gradually decreases (S.N. 20, 21). The strain pattern recorded for the hanging wall samples clearly shows an increasing trend of $\bar{\varepsilon}_{s}$ value away from the thrust surface (Fig. 4).

\section{Thrust-related strain heterogeneity}

Tectonic discontinuities like thrusts record a major discontinuous strain partitioning during deformation of the crust. Although we have only limited samples, we attempt to compare the strain parameters $\left(\bar{\varepsilon}_{s}\right.$ and $\left.v\right)$ in terms of distance normal to the MT in the both footwall and hanging wall unit. This approach clearly indicates apparent discontinuities in the strain parameters (Fig. 5). The footwall block shows a gradual increase in $\bar{\varepsilon}_{s}$ value towards the MT but this trend is reversed in the hanging wall where the $\bar{\varepsilon}_{s}$ value is lower immediately above the MT and gradually increases away from the MT with some minor fluctuations. These trends are consistent with other studies (e.g. Jain and Anand 1988; Kawamitsu and Hayashi 1991) in similar tectonostratigraphic level in the Himalaya. Further, south of the MT we observe small fluctuation in this trend indicating medium strain zone with oblate type strain field.

\section{D shape of strain ellipsoids}

We show the shape of strain ellipsoid by calculating strain ellipses via least square method (Hayashi 1994, 2001) from three non-parallel sections. Figure 6 shows the location, shape, and orientation of the calculated strain ellipsoids for the Malekhu area. In the strain ellipsoid, X, Y, and Z represent the principal strain axes on a lower hemispherical equal area projection and a circle represents the Schmidt net circle. The centre of each symbol (X, Y, and Z) indicates its direction. In each shape of strain ellipsoid, the accompanied ellipse denotes XZ plane of strain ellipsoid, which is actually on an inclined plane and is drawn so that it seems a horizontal 


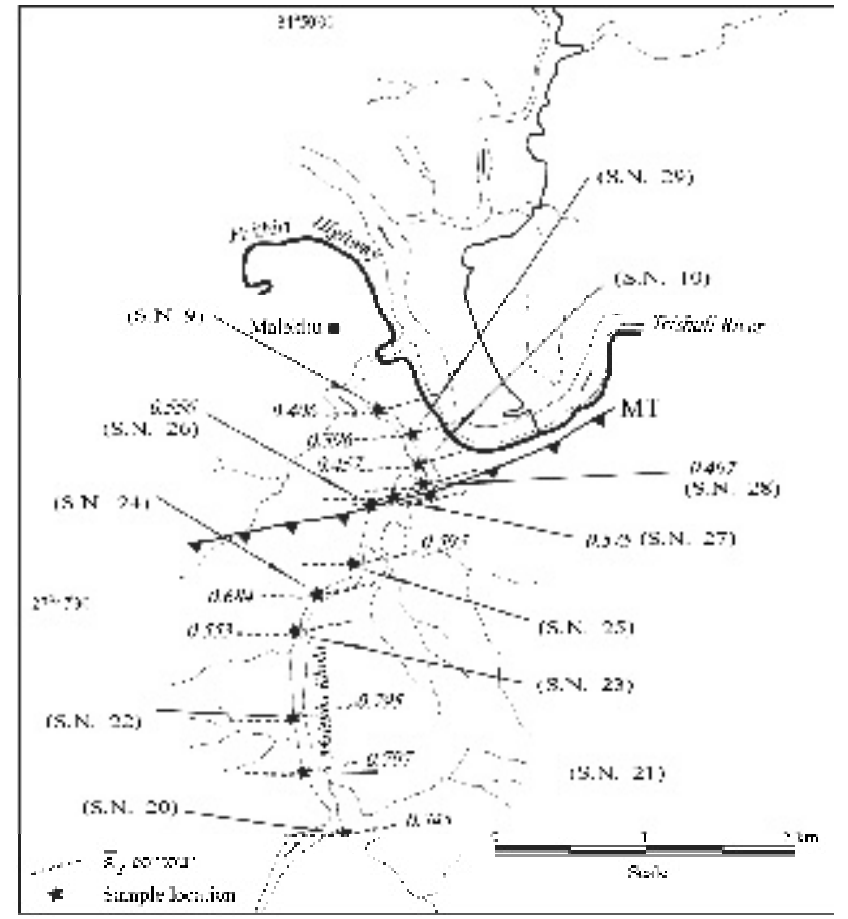

Fig. 4: Distribution of Nadai's amount of strain intensity

$\left(\bar{\varepsilon}_{s}\right) . \bar{\varepsilon}_{s}=\frac{\sqrt{3}}{2} \bar{\gamma}_{o c t}$,

where $\bar{\gamma}_{o c t}=\frac{2}{3} \sqrt{\left(\varepsilon_{1}-\varepsilon_{2}\right)^{2}+\left(\varepsilon_{2}-\varepsilon_{3}\right)^{2}+\left(\varepsilon_{3}-\varepsilon_{1}\right)^{2}}$, and

$\varepsilon_{1}=\ln \left(1+e_{1}\right), \varepsilon_{2}=\ln \left(1+e_{2}\right), \varepsilon_{3}=\ln \left(1+e_{3}\right)$,

plane. From this, we explain the ratio of the length of the $X$ and Z. A Flinn diagram gives the shape of the strain ellipsoid. This represents three types of strain ellipsoid, i.e. oblate $(k=0)$, prolate $(k=\infty)$, and plane strain type $(k=1)$. The Flinn plot shows that finite strain in the metamorphic rocks is of prolate and oblate types for the footwall and dominantly oblate type for the hanging wall (Figs. 7a and b). Only one sample of the hanging wall block falls on the prolate strain field and is characterised by a lower magnitude of strain intensity (Figs. 7a and b). The footwall samples show a lower $\bar{\varepsilon}_{s}$ value. Similarly, the samples showing oblate type ellipsoids are of relatively higher $\bar{\varepsilon}_{s}$ value (Figs. 7a and b). However, none of the samples show the plane strain type, even near to the MT. The X-axis of the strain ellipsoids reveals NE-SW and NW-SE trends.

\section{Strain controlled microstructure and deformation mechanisms}

Although quartz is a common mineral of metamorphic rocks, its deformation mechanisms is still incompletely understood because the deformation processes and microstructural development are strongly depend on strain rate, temperature, differential stress, and presence of water in the lattice and along the grain boundaries (Passchier and
Trouw 2005). Considering its abundance and sensitivity to deformation, we consider quartz grain as a tectonic indicator to study deformation mechanism. Since the complete sequence of both footwall and hanging wall is well exposed in the study area, detailed studies on microstructures developed both in footwall and hanging wall quartzites and schists of MT in terms of strain intensity have allowed us to decipher deformation mechanisms on a micro scale. It further helps us to study systematic changes in microstructures with respect to MT. We looked microstructure from the basal part of the footwall where fault rocks (mylonitic quartzites) have weak foliation defined by grain shape preferred orientation. The quartz grains are inequigranular and associated with poorly developed interlobate grain boundaries. Typical features of these grains are distinct deformation lamellae and strong undulatory extinction (Fig. 8a). These features are characteristic of an intracrystalline creep at the lower temperature (Passchier and Trouw 2005). The mylonitic foliation is defined by a preferred alignment of coarse and fine grains. The relative strain intensity, $\bar{\varepsilon}_{s}$, for this sample (S.N. 9) is measured to 0.406. The polygonal quartz grains display polycrystalline ribbon structure (Fig. $8 b$ ). Vauchez (1980) suggests that the ribbons are produced by solid-state segregation of quartz into the flattening plane. Dynamic recrystallisation seems to allow the initiation of a solid-state segregation of strain-free new grains. The lensshaped aggregates, which were originated from the recrystallisation of one or a few neighbouring grains, become more and more elongated until they transform to polycrystalline ribbons. This entire deformation mechanism is due to simple shearing. Towards the thrust surface, recrystallised quartz grains exhibit almost polygonal fabrics with irregular and interlobate boundaries with the adjacent grains. Pressure solution features are distinctly shown by strongly indented, curved, and sutured contacts. Strong undulatory extinction due to a high dislocation density clearly indicates dynamic recrystallisation (Fig. 8c). Sample S.N. 29 shows a comparatively lower strain intensity value $\left(\bar{\varepsilon}_{s}=\right.$ $0.396)$. With an increasing strain intensity value near the thrust surface, feldspar grains are fragmented in a ductile matrix forming a micro shear zone (Fig. 8d). This sample records a relatively higher strain intensity value $\left(\bar{\varepsilon}_{s}=0.457\right)$ (S.N. 10).

The lower part of hanging wall is dominantly composed of pelitic schist showing an intense effect of thrusting. The quartz grains are highly deformed and often fractured. They are flattened and elongated parallel to the foliation plane defined by platy minerals (Fig. 8e). These grains show a higher strain intensity value $\left(\bar{\varepsilon}_{s}=0.556\right)$ (S.N. 26). The elongated quartz grains with straight and smoothly curved boundaries often show the ribbon structure. In contrast to the footwall samples, quartz grains in this sample lack undulatory extinction showing a strong effect of static recrystallisation. Further above, the rock gradually exhibits the S-C fabric in the pelitic schists of the Kalitar Formation (Fig. 8f). The platy minerals such as biotite and muscovite define the shear plane. The associated quartz grains show the effect of static recrystallisation. Some quartz grains show 


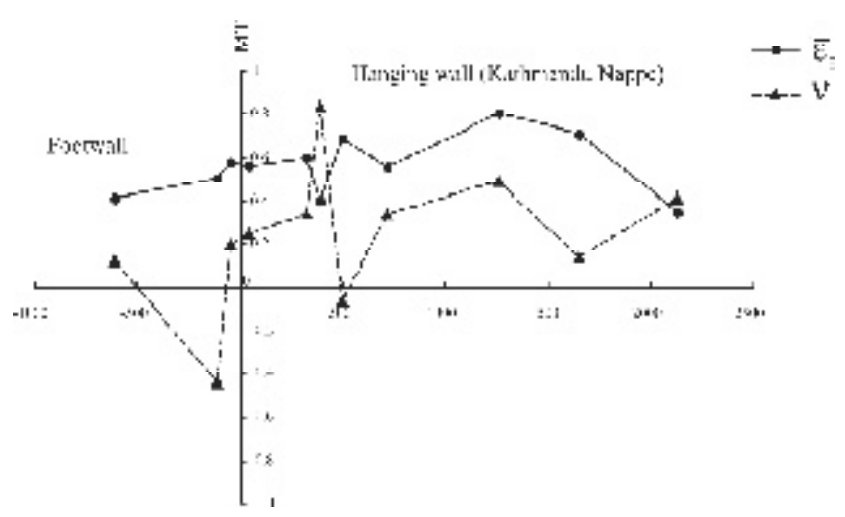

Fig. 5: Variation of strain parameters across the MT in Malekhu area. Note that measured distance is normal to the MT.

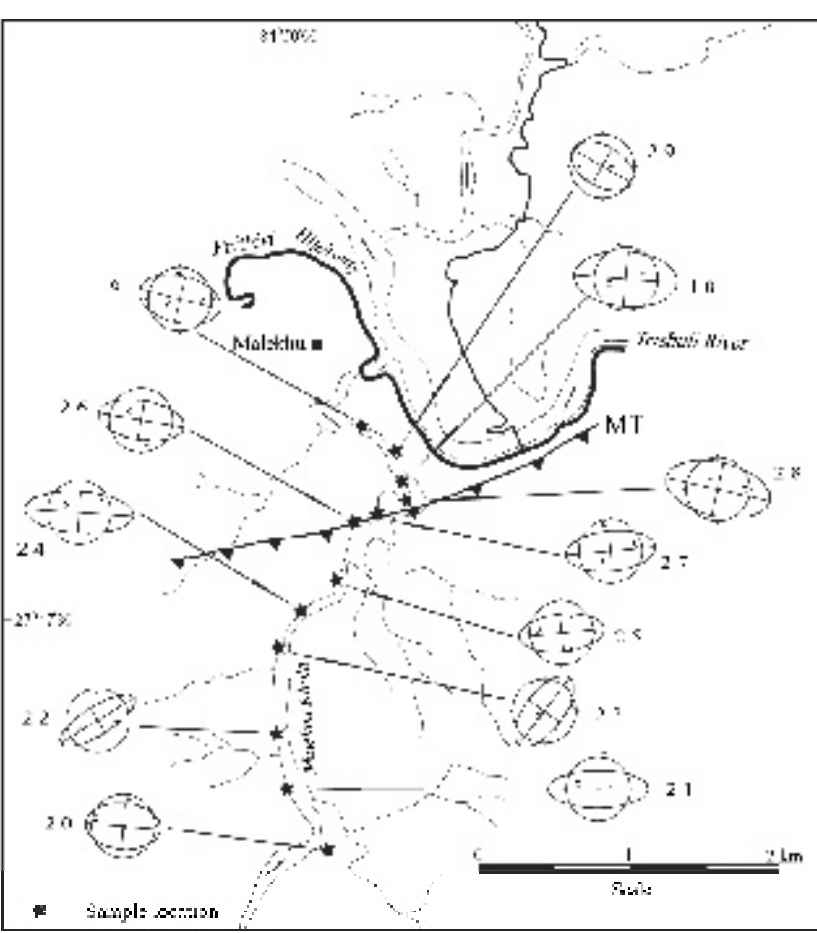

Fig. 6: Spatial distribution of 3D strain ellipsoids

a mild undulatory extinction. This is probably due to a new phase of deformation inducing the undulatory extinction and dynamic recrystallisation. Further south, the quartz fabric is more or less the same with the exception of increasing relative strain intensity, and its deformation mechanism is predominated by static recrystallisation.

In summary, the footwall of the MT was affected by dynamic recrystallisation at lower temperatures $\left(330-470^{\circ} \mathrm{C}\right.$; Beyssac et al. 2004) with a lower strain intensity values. Towards the MT, the intensity of deformation also increases with an increase in strain intensity. The polycrystalline ribbon

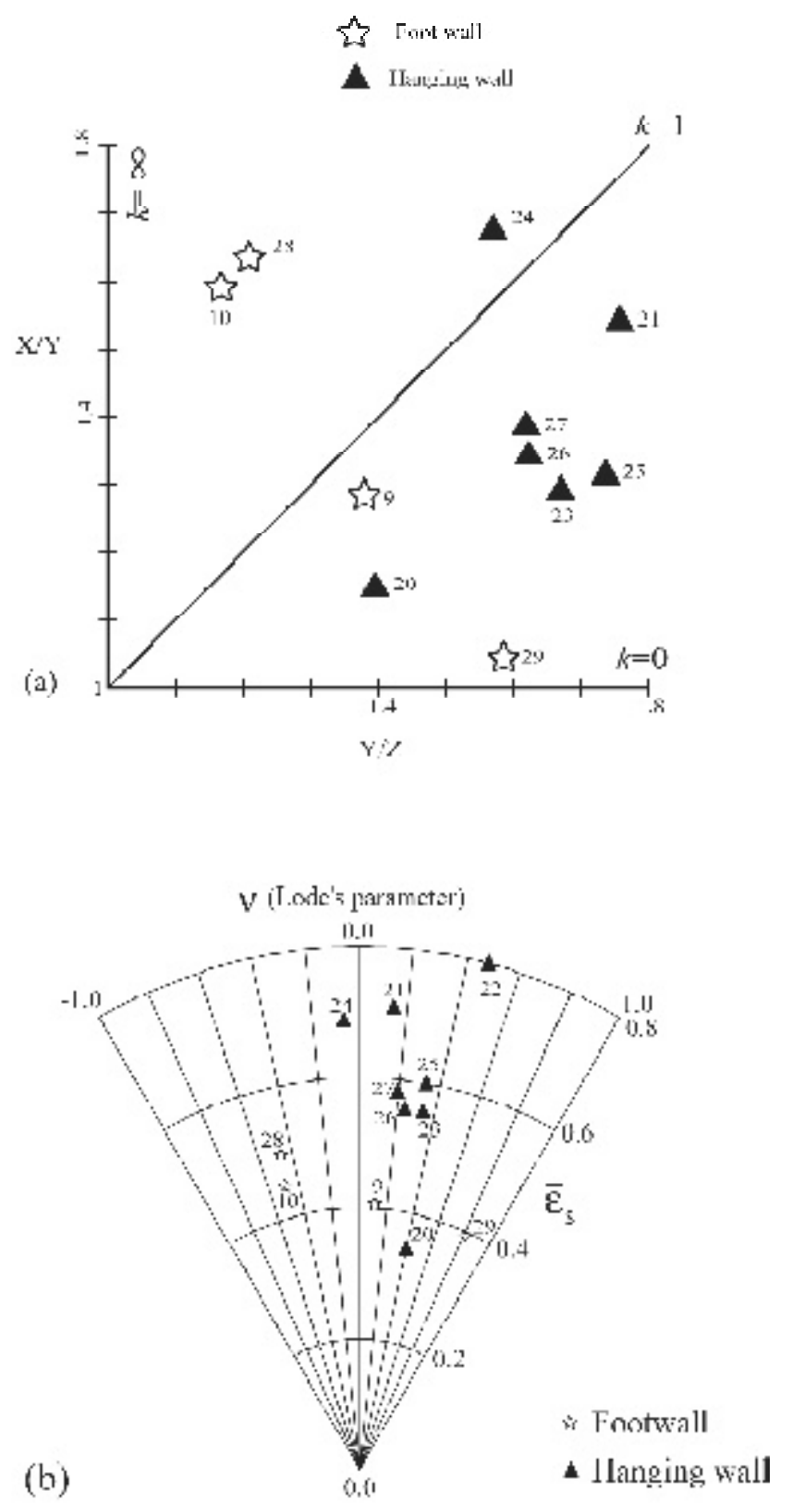

Fig. 7: (a) Flinn diagram for finite strain geometry in Malekhu area (b) Hossack's diagram

structures developed in the mylonitic quartzite of footwall is indicative of simple shear deformation during the emplacement of the Kathmandu Nappe. In contrast, the hanging wall was dominantly affected by static recrystallisation at relatively higher temperatures $\left(530-686^{\circ} \mathrm{C}\right.$; Johnson et al. 2001) than that of the footwall.

\section{DISCUSSION}

\section{Interpreting strain variation pattern}

The footwall comprises phyllites at the basal part, mylonitic quartzites in the middle part, and phyllonites at 

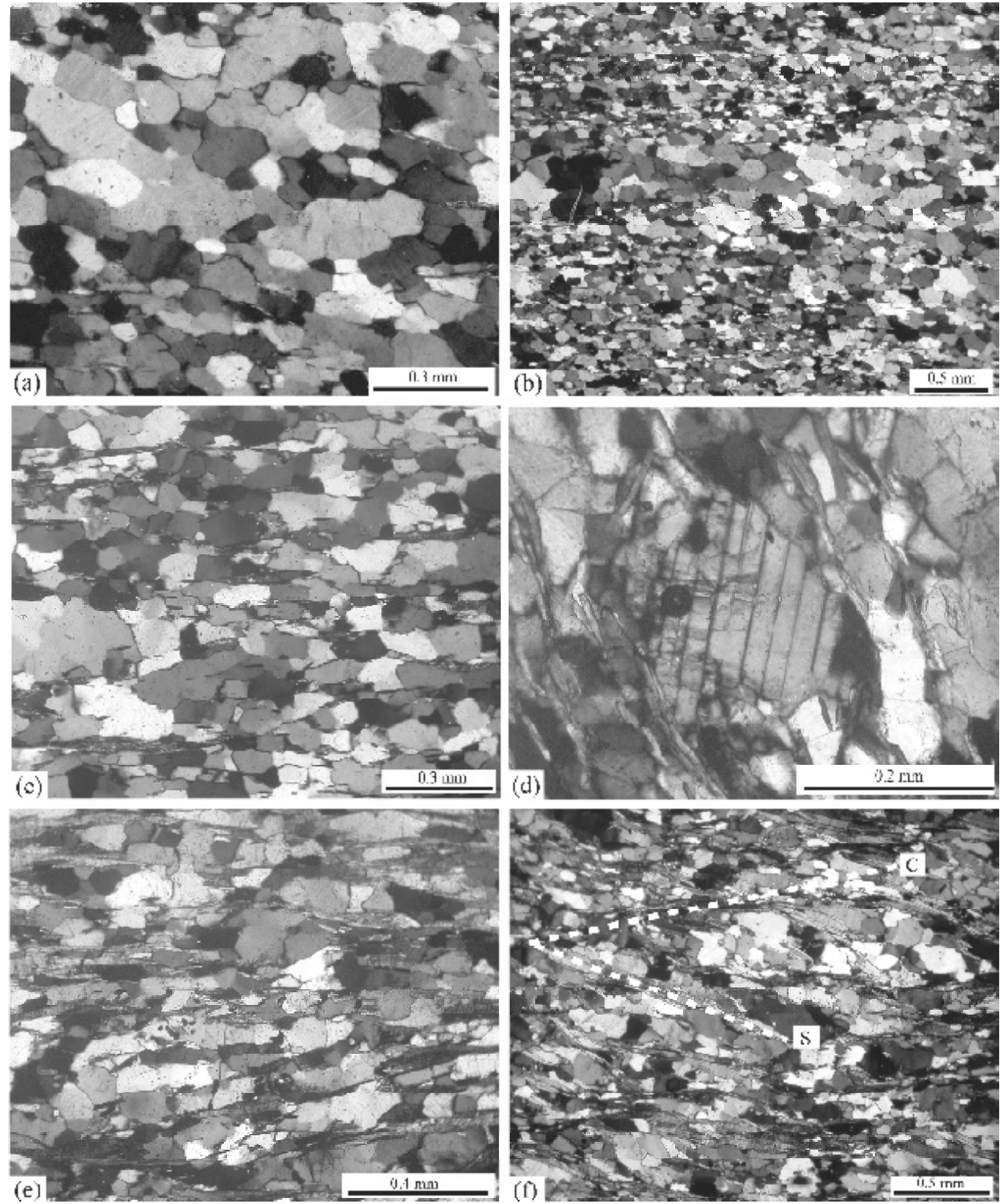

Fig. 8: Microstructures. (a) Quartz grains with deformation lamellae showing intense intracrystalline deformation about $300 \mathrm{~m}$ below the MT. (b) Ribbon structures developed in polycrystalline quartzite of the footwall. (c) Dynamically recrystallised quartz grains for footwall. Note the strong undulatory extinction. (d) Microshear zone developed in feldspar grain in ductile matrix in footwall quartzite. (e) Ribbon structures in micaceous quartzites of the hanging wall showing static recrystallisation. (f) S-C fabrics developed in schist of the hanging wall block. 
the MT zone. The hanging wall is composed of phyllonites, mylonites, and schists at the basal part, which are overlain by quartzites having a different matrix-clast proportion with an intercalation of high-grade schists. This lithological variation has a significant contribution to the strain heterogeneity. Similarly, grain size variation and composition equally control the rheology of the rocks in the case of pressure solution mechanisms (Dittmar et al. 1994), which in turn affect the strain state. Although small-scale strain heterogeneity is not the major interest of this study, we have found heterogeneous strain patterns in both footwall and hanging wall rocks. In general, the estimated strain intensity shows relatively higher value for the schist and micaceous quartzite samples. Particularly, the quartzite samples having an equal quartz-mica proportion and fine grain size gave a relatively higher strain intensity values as compared to those of the coarse-grained ones.

\section{Interpreting strain ellipsoid}

The deformed grains estimate only the finite strain state resulting from multiple deformation phases. It should be noted that the partially recrystallised grains obviously introduce some error into the strain measurements due to their irregular grain boundaries. However, computed strain ellipsoids can still be useful for the kinematic interpretation. The spatial distribution of strain ellipsoid reveals variation in strain ellipsoid especially close to the MT (Fig. 6). The long axes of the strain ellipsoids are oriented along ESE consistent with the SE directed thrusting revealed by regional trend of lineations, and meso and micro-scale shear sense indicators. Few ellipsoids (S.N. 22 and 23) are oblique to the regional transport direction in the middle part of the hanging wall block. It is possible to have such direction because direction of maximum elongation may switch from parallel to perpendicular direction as the strain dissipates during emplacement of thrust sheet (Tikoff and Greene 1997). The prolate strain fields observed in the footwall indicate heterogeneous simple shear and estimated $\bar{\varepsilon}_{s}$ values increases towards the MT. In the hanging wall, however, $\bar{\varepsilon}$ increases away from the MT and strain ellipsoids are of dominantly oblate type with a few prolate type ellipsoids. Therefore, simple shear deformation was probably active for the internal deformation in the footwall block and pure shear with sub-simple shear component is responsible for the internal deformation of the hanging wall block.

\section{CONCLUSIONS}

Mesoscopic structures, finite strain patterns, microtextures, and deformation mechanisms change systematically with the structural position and lithology across the MT in the Malekhu area. Strain data from quartzite beneath the MT and quartzite and schist above the MT are consistent with top to the southeast shear direction recorded from the microtectonic indicators. In the footwall Nadai's amount of strain intensity $\left(\bar{\varepsilon}_{s}\right)$ varies from 0.396 to 0.575 , which generally shows an increasing trend towards the proximity of the MT. However, hanging wall reveals increasing trend of $\bar{\varepsilon}_{s}$ magnitude away from the MT and varies from 0.556 (at the basal part) to 0.795 (upper part). Microscopic textures and microstructures have revealed dynamic recrystallisation for the underlying footwall rocks and static recrystallisation for the overlying hanging wall rocks. The geometry of three-dimensional strain ellipsoids, microstructures, and grain-scale deformation mechanisms have shown that the footwall was dominantly affected by simple shear at low temperatures while the hanging wall suffered from pure shear with minor sub-simple shear at relatively higher temperatures.

\section{ACKNOWLEDGEMENTS}

D C is grateful to Professor B. N. Upreti, Dean, Institute of Science and Technology, Tribhuvan University, Nepal, and Dr R. Shinjo, Department of Physics and Earth Sciences, University of the Ryukyus, Japan for providing laboratory facilities. We thank Y. Sunagawa, University of the Ryukyus, Japan, M. P. Koirala, T. P. Bhattarai and P. Paudyal of Tribhuvan University, Nepal for their assistance in the field and laboratory works. We also acknowledge great effort of Shiva and Mohan for preparation of thin sections. This research was financially supported by the Sasakawa Scientific Research Grant (No: 247/2005) from the Japan Science Society.

\section{APPENDIX}

\section{The least-square method}

Following Owens (1984) and De Paor (1990), Hayashi (1994) has developed the method, which can construct a strain ellipsoid using strain ellipses from three non-parallel sections. In this method, the entire calculation is divided into two parts: two-dimensional strain analysis and threedimensional strain analysis. For the two-dimensional strain analysis, fabric method (Wheeler 1986) is used. It needs an algebraic treatment only. In this method, strain marker ellipses are deformed by deformation tensor $\mathrm{D}$ and are averaged into a fabric ellipse (Fig. A1). Further, we can calculate strain ellipse from the deformation tensor D. However, this method assumes that (1) the strain markers are of elliptical shape without initial foliation and were deformed in homogeneous finite strain condition (2) no ductility contrast exists between the strain marker and matrix. As compared to $R_{f} / \varnothing$ method (Ramsay 1967, Dunnet 1969; Dunnet and Siddans 1971; Lisle 1977, 1985), this method is easy because it does not have manual interruption in calculation. As we obtained the direction of long axis and the axial ratio of the strain ellipses on the planes A, B, C, (Fig. A2), three dimensional strain can be computed by calculating:

(1) The relative axial length of the strain ellipses using GS method (Hayashi 1994, 2001).

(2) The shape tensor of the strain ellipsoid that is constructed from the strain ellipses by least square strain technique. 


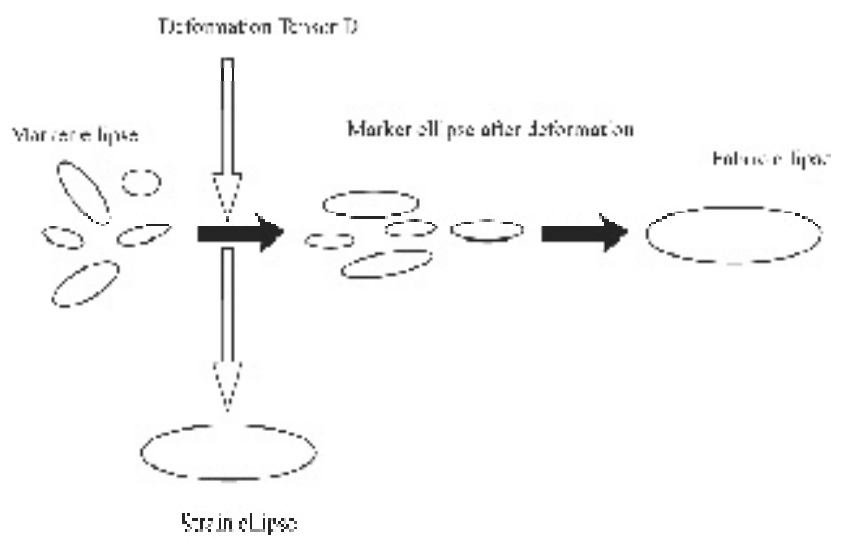

Fig. A1: Fabric method

(3) The axial lengths X, Y, Z using the eigen values of the shape tensor of the strain ellipsoid assuming that $\lambda_{1} \leq \lambda_{2} \leq \lambda_{3}$ where $\lambda_{1}, \lambda_{2}$, and $\lambda_{3}$ are the eigen values of the shape tensor. The axial lengths of the strain ellipsoid can be calculated as

$X=\sqrt{\frac{1}{\lambda_{1}}}, Y=\sqrt{\frac{1}{\lambda_{2}}}$, and $Z=\sqrt{\frac{1}{\lambda_{3}}}$

where $X>Y>Z$.

(4) The directions of $X, Y, Z$ of the strain ellipsoid using the eigen vectors of the shape tensor.

The directions of $\mathrm{X}, \mathrm{Y}$ and $\mathrm{Z}$ equal to that of the eigen vectors which correspond with the $\lambda_{1}, \lambda_{2}$, and $\lambda_{3}$ respectively (for details, see Hayashi 1994, 2001).

\section{REFERENCES}

Arita, K., Dallmeyer, R. D., and Takasu, A., 1997, Tectonothermal evolution of the Lesser Himalaya, Nepal: constraints from ${ }^{40} \mathrm{Ar} /{ }^{39} \mathrm{Ar}$ ages from the Kathmandu Nappe. The Island Arc, v. 6, pp. 372-385.

Arita, K., Takasu, A., Dhital, M. R., Regmi, K. R., Hamaguchi, H., and Matsuoka, Y., 2001, Nappe tectonics in the Kathmandu area, central Nepal: Single Nappe? Or double nappes? Jour Asian Earth Sci., v. 16 (3A), 3 (Sp. Issue of $16^{\text {th }}$ HKT Workshop).

Beyssac, O., Bollinger, L., Avouac, J. P., and Goffé, B., 2004, Thermal metamorphism in the Lesser Himalaya of Nepal determined from Raman spectroscopy of carbonaceous material. Earth Planet. Sci. Lett., v. 225, pp. 233-241.

Brunnel, M., 1986, Ductile thrusting in the Himalayas: shear sense criteria and stretching lineations. Tectonics, v. 5, pp. 247-265.

Burchfield, B. C., Zhiliang, C., Hodges, K. V., Yuping L., Royden, L., Changrong, D., and Jiene, X., 1992, The South Tibetan Detachment System, Himalayan orogen: extension contemporaneous with and parallel to shortening in a collisional belt. Geol. Soc. Ame. Sp. Pap., v. 269, pp. 1-41.

De Paor, D. G., 1990, Determination of the strain ellipsoid from sectional data. Jour. Struct. Geol., v. 12, pp. 131-137.

DeCelles, P. G., Robinson, D. M., Quade, J., Ojha, T. P., Garzione, C.N., Copeland, P., and Upreti, B. N., 2001, Stratigraphy,

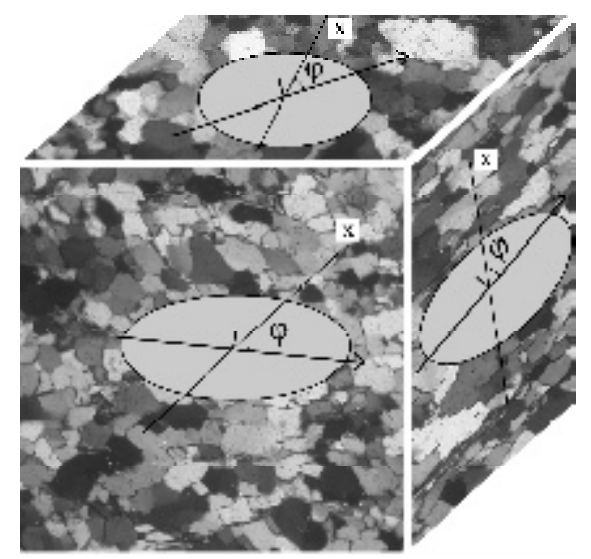

Fig. A2: Strain ellipses marked on oriented sample

structure, and tectonic evolution of the Himalayan fold-thrust belt in western Nepal. Tectonics, v. 20, pp. 487-509.

Dittmar, D., Meyer, W., Oncken, O., Schievenbusch, T.H., Walter, R., and von Winterfled, C., 1994, Strain portioning across a fold and thrust belt: the Rhenish Massif, Mid-European Variscides. Jour. Struct. Geol., v. 16, pp. 1335-1352.

Dunnet, D., 1969, A technique of finite strain analysis using elliptical particles. Tectonophysics, v. 7, pp. 117-136.

Dunnet, D. and Siddans, A. W. B., 1971, Non-random sedimentary fabrics and their modification by strain. Tectonophysics, v. 12, pp. 307-325.

Gansser, A. 1964, Geology of the Himalaya. Wiley Interscience, London, $289 \mathrm{p}$.

Hayashi, D., 1994, Three-dimensional finite strain analysis techniques from strain ellipses on non-parallel sections. Jour. Geol. Soc. Japan, v. 100, pp. 150-161. (in Japanese with English abstract).

Hayashi, D., 2001, The technique that constructs strain ellipsoid from three strain ellipses measured on non-parallel sections based on the least square method and factors that control precision of strain. Bull. Fac. Sci., University of the Ryukyus, No. 71, pp. 47-70.

Jain, A. K. and Anand, A., 1988, Deformational and strain patterns of an intracontinental collision ductile shear zone: an example from the Higher Garhwal Himalaya. Jour. Struct. Geol., v. 10, pp. 717-734.

Johnson, M. R. W., Oliver, G. J. H., Parrish, R. R., and Johnson, S. P., 2001, Synthrusting metamorphism, cooling, and erosion of the Himalayan Kathmandu Complex, Nepal. Tectonics, v. 20, pp. 394-414.

Kawamitsu, K. and Hayashi, D., 1991, Geology and threedimensional finite strain analysis around Annapurna Himal, central Nepal. Bull. Fac. Sci., University of the Ryukyus, No. 52, pp. 37-52.

Le Fort, P., 1975, Himalayas: the collided range. Present knowledge of the continental arc. Ame. Jour. Sci., v. 275-A, pp. 1-44.

Lisle, R. J., 1977, Clastic grain shape and orientation in relation to cleavage from the Aberystwyth grits, Wales. Tectonophysics, v. 39, pp. 381-395.

Lisle, R. J., 1985, Geological strain analysis: A manual for the $R / \varnothing$ method. Pergamon, $99 \mathrm{p}$.

Mukul, M. and Mitra, G., 1998, Finite strain and strain variation analysis in the Sheeprock thrust sheet: an internal thrust sheet in the Provo salient of the Sevier fold-and-thrust belt, Central Utah. Jour. Struct. Geol., v. 20, pp. 403-417. 
Nadai, A., 1963, Theory of flow and fracture of solids. Engineering Societies Monographs, McGraw-Hill, New York, 705 p.

Owens, W. H., 1984, The calculation of a best-fit ellipsoid from elliptical sections on arbitrarily oriented planes. Jour. Struct. Geol., v. 6, pp. 571-578.

Passchier, C. W. and Trouw, R. A. J., 2005, Microtectonics. Springer, Germany 366 p.

Rai, S. M., 2001, Geology, geochemistry, and radiochronology of the Kathmandu and Gosainkund Crystalline nappes, central Nepal Himalaya. Jour. Nepal Geol. Soc., v. 25, pp. 135-155.

Rai, S. M., Guillot, S., Le Fort, P., and Upreti, B. N., 1998, Pressuretemperature evolution in the Kathmandu and Gosainkund regions, central Nepal. Jour. Asian Earth Sci., v. 16, pp. 283298.

Ramsay, J. G., 1967, Folding and fracturing of rocks. McGrawHill, New York, p.

Sanderson, D. J., 1982, Models of strain variation in nappes and thrust sheets: a review. Tectonophysics, v. 88, pp. 201-233.

Schelling, D. and Arita, K., 1991, Thrust tectonics, crustal shortening and the structure of the far eastern Nepal Himalaya. Tectonics, v. 10, pp. 851-862.

Srivastava, P. and Mitra, G., 1994, Thrust geometries and deep structure of the outer and lesser Himalaya, Kumaon and Garhwal (India): Implications for evolution of the fold-andthrust belt. Tectonics, v. 13, pp. 89-109.
Stöcklin, J., 1980, Geology of the Nepal and its regional frame. Jour. Geol. Soc. London, v. 137, pp. 1-34.

Stöcklin, J. and Bhattarai, K. D., 1977, Geology of Kathmandu area and Mahabharat Range, Nepal Himalaya. HMG/Nepal/ UNDP Report, $64 \mathrm{p}$.

Strine, M., and Wojtal, S. F., 2004, Evidence for non-plane strain flattening along the Moine thrust, Loch Srath nan Aisinnin, North-West Scotland. Jour. Struct. Geol., v. 26, pp. 1755-1772.

Takagi, H., Arita, K., Sawaguchi, T., Kobayashi, K., and Awaji, D., 2003, Kinematic history of the Main Central Thrust zone in the Langtang area, Nepal. Tectonophysics, v. 366, pp. 151-163.

Tikoff, B. and Greene, D., 1997, Stretching lineations in transpressional shear zone Jour. Struct. Geol., v. 19, pp. 29-40.

Upreti, B. N. and Le Fort, P., 1999, Lesser Himalayan crystalline nappes of Nepal: problem of their origin. In: Macfarlane, A., Quade, J., Sorkhabi , R., (Eds.), Geol. Soc. Ame. Spec. Pap., v. 328, pp. 225-238.

Valdiya, K. S., 1980, Two intracrustal boundary thrusts of the Himalaya. Tectonophysics, v. 66, pp. 323-348.

Vauchez, A., 1980, Ribbon texture and deformation mechanisms of quartz in mylonitised granite of Great Kabylia (Algeria). Tectonophysics, v. 67, pp. 1-12.

Wheeler, J., 1986, Average properties of ellipsoidal fabrics: implication for two-and three-dimensional methods of strain analysis. Tectonophysics, v. 126, pp. 259-270. 